\title{
STUDI PENGETAHUAN SISWA TERHADAP JENIS, KHASIAT DAN CARA PEMANFAATAN TANAMAN OBAT YANG TERDAPAT DI LINGKUNGAN SEKOLAH
}

\author{
Diana Zulyetti \\ STKIP Yayasan Abdi Pendidikan Payakumbuh \\ dayanaevan86@gmail.com
}

\begin{abstract}
ABSTRAK
Penelitian ini bertujuan untuk mengetahui sejauh mana pengetahuan siswa SMP Negeri 3 Kecamatan Payakumbuh terhadap jenis, khasiat dan cara pemanfaatan tanaman obat yang terdapat di lingkungan sekolah. Metode dalam penelitian ini adalah metode survey. Pengambilan sampel dilakukan dengan mengambil 15\% dari keseluruhan siswa kelas VII dan siswa kelas VIII dan didapatkan sebanyak 41 orang siswa. Pengumpulan data tentang pengetuahuan siswa terhadap jenis, manfaat dan cara pengolahan tanaman berkhasiat obat dilakukan menggunakan angket. Hasil penelitian menunjukan bahwa 68,0\% siswa SMP Negeri 3 Kecamatan Payakumbuh telah mengetahui jenis-jenis tanaman obat yang ada di lingkungan sekolah dengan tingkat pengetahuan dikategorikan mengetahui, sebanyak $66,0 \%$ siswa mengetahui tentang manfaat tanaman obat yang dikategorikan mengetahui, dan 69,9\% siswa mengetahui pengolahan tanaman obat yang dikategorikan mengetahui. Simpulan, sebagian besar siswa memiliki pengetahuan mengenai tanaman obat yang berada dilingkungan sekolah dengan tingkat kategori mengetahui, mulai dari jenis, manfaat dan cara pengelolaan tanaman obat.
\end{abstract}

Kata Kunci : pengetahuan, jenis, khasiat, manfaat, tanaman obat

\begin{abstract}
This study aims to determine the extent of the knowledge of students of SMP Negeri 3 Payakumbuh District on the types, efficacy and ways of utilizing medicinal plants found in the school environment. The method in this study is a survey method. Sampling was done by taking $15 \%$ of all students in class VII and class VIII and obtained as many as 41 students. Data collection on students' knowledge of the types, benefits and methods of processing medicinal plants was carried out using a questionnaire. The results showed that $68.0 \%$ of SMP Negeri 3 Payakumbuh students knew the types of medicinal plants in the school environment with knowledge categorized as knowing, as many as $66.0 \%$ of students knew about the benefits of medicinal plants categorized as knowing, and 69, 9\% of students know that processing medicinal plants is categorized as knowing. Conclusion, most students have knowledge about medicinal plants in the school environment with a category level to know, starting from the types, benefits and ways of managing medicinal plants.
\end{abstract}

Keywords: knowledge, types, Benefits benefits, medicinal plants 


\section{PENDAHULUAN}

Kekayaan alam tumbuhan di Indonesia meliputi 30.000 spesies tumbuhan dari total 40.000 spesies tumbuhan di dunia, 940 spesies diantaranya merupakan tumbuhan berkhasiat obat (Masyhud, 2010).

Tumbuhan obat merupakan seluruh spesies tumbuhan yang diketahui mempunyai khasiat obat dimana dapat menghilangkan rasa sakit, meningkatkan daya tahan tubuh, membunuh bibit penyakit dan memperbaiki organ yang rusak (Agromedia, Redaksi. 2003). Bagian tanaman obat yang sering digunakan berupa akar, kulit batang, kayu, daun, bunga atau bijinya (Adfa, 2005). Pengetahuan tentang tanaman berkhasiat obat berdasar pada pengalaman dan keterampilan yang secara turun temurun telah diwariskan dari satu generasi ke generasi berikutnya.

Selain itu, arti penting tanaman obat tradisional bagi kehidupan manusia perlu mendapat perhatian serius, terutama dari anak-anak muda sebagai generasi penerus, di samping karena tanaman langka yang dimiliki Indonesia semakin bertambah jumlah statusnya menjadi terancam punah, juga karena kecilnya perhatian terhadap uji klinis tanaman, khususnya tanaman obat, seperti yang diungkapkan dalam majalah Trubus dengan tema Infokit Herbal Indonesia Berkasiat dikatakan bahwa tanaman ungulan nasional yang telah diuji klinis baru 9, yaitu salam, sambiloto, kunyit, jaher merah, jati belanda, temulawak, jambu biji, cabai jawa, dan mengkudu (Trubus, 2010). Bukti kecilnya perhatian terhadap tanaman obat, menurut Hariana, di Indonesia dikenal lebih dari 20.000 jenis tumbuhan obat. Namun, baru 1.000 jenis saja yang sudah didata, dan baru sekitar 300 jenis yang sudah dimanfaatkan untuk pengobatan tradisional (Hariana, 2009). Hal ini menunjukkan betapa kecilnya perhatian maupun penggunaan tanaman obat.

Seiring dengan berkembangnya pemanfaatan tanaman obat di masyarakat, Sekolah juga tidak ketinggalan mulai memperkenalkan tanaman obat dengan cara membudidayakan tanaman obat tersebut di lingkungan sekolah. Berdasarkan hasil investigasi awal mengenai jenis-jenis tanaman yang berkhasiat obat yang terdapat di SMPN 3 Kecamatan Payakumbuh, ditemukan bahwa terdapat beberapa jenis tanaman yang berkhasiat obat di lingkungan sekolah, seperti tanaman jambu biji (Psidium guajava.L), Lidah buaya (Aloe vera L), jahe (Zingiber officinale Roscoe), Temulawak (Curcuma xanthrorrhiza ROXB), Cabe rawit (Capsicum frustescens. L), Sirsak (Annona muricata. L), Kunyit (Curcuma domestica), Betadin (Jatropha multifida L), Seledri (Apium graveolens L), Cocor bebek (Kalancheo pinnata .L), Pepaya (Carica papaya. L), talas (Colocasia esculenta. L), Pisang (Musa paradisiacal), Lengkuas (Alpina galanga. L), Jeruk nipis (Citrus aurantiifolia).

Alam yang paling dekat dengan siswa adalah tumbuhan, obat tradisonal banyak berasal dari tumbuhan dan mudah ditemui siswa saat di sekolah maupun di rumah, tanaman yang berkhasiat obat di lingkungan sekolah juga bisa 
dimanfaatkan sebagai pertolongan pertama kalau ada siswa yang terluka dan sakit. Selain itu obat tradisional memiliki manfaat yang banyak, harganya murah, dan bisa dipetik kapan saja (Widodo, 2013).

Memperkenalkan tanaman obat harus dimulai sejak dini kepada anak-anak muda terutama usia remaja, karena pada usia ini keingintahuannya sudah semakin besar, mereka sudah mulai belajar menentukan pilihan. Pengetahuan mengenai tanaman yang berkhasiat obat bisa menjadi salah satu tambahan informasi bagi remaja-remaja SMP.

Oleh karena itu, penting untuk mengetahui tingkat pengetahuan siswa SMP Negeri 3 Kecamatan Payakumbuh tentang jenis-jenis tanaman yang berkhasiat obat di lingkungan sekolah, apa manfaat dari tanamna tersebut, dan bagaimana cara pemanfaatan atau pengolahan tanaman tersebut sebagai obat, karena SMPN 3 Kecamatan Payakumbuh merupakan Sekolah Adiwiyata dan pernah mendapatkan piagam Adiwiyata Nomor 1 tingkat nasional di tahun 2013. Sekolah telah dilengkapi dengan Kebun Apotek Hidup serta juga memiliki Green House, yang dibangun untuk membudidayakan berbagai jenis tanaman termasuk tanaman yang berkhasiat obat.

Diperkirakan siswa belum mengetahui jenis dan tanaman apa saja yang bisa dimanfaat sebagai obat dan bagaiman pengolahannya di sekolah ini. Oleh karena itu, penelitian ini bertujuan untuk mengetahui sejauh mana pengetahuan siswa SMPN 3 Kecamatan Payakumbuh terhadap nama atau jenis tumbuhan obat yang ada di sekolah, apa manfaatnya dan bagaimana pengolahan tanaman tersebut dijadikan sebagai obat. Penelitian ini bertujuan untuk mengetahui sejauh mana pengetahuan siswa SMP Negeri 3 Kecamatan Payakumbuh terhadap jenis, khasiat dan cara pemanfaatan tanaman obat yang terdapat di lingkungan sekolah

\section{METODE PENELITIAN}

Penelitian ini dilaksanakan dari April sampai Juni 2019 di SMP Negeri 3 Kecamatan Payakumbuh, Berlokasi di Taeh Baruah-Limbanang Kecamatan Payakumbuh Kabupaten lima puluh kota.

Jenis penelitian ini adalah kualitatif deskriptif. Penelitian kualitatif adalah penelitian yang prosedur penelitiannya yang menghasilkan data deskriptif berupa kata-kata tertulis atau lisan dari orang-orang yang dapat di amati (Meleong, 2008).

Metode penelitian ini adalah metode survei. Metode survei adalah penyelidikan yang dilakukan untuk memproleh fakta-fakta dari gejala-gejala yang ada dan mencari keterangan- keterangan yang secara faktual yang di dapat dari hasil wawancara atau angket tertentu melalui informan penelitian

Alat penelitian yang di gunakan dalam penelitian ini adalah kuesioner. Kuesioner diberikan kepada siswa kelas VII dan kelas VIII SMP Negeri 3 Kecamatan Payakumbuh yang merupakan Informan penelitian dengan format sebagai berikut;(1) Penyusunan Angket tinjauan pengetahuan siswa terhadap jenis tanaman obat dilakukan dengan berdasarkan skala Likert 1-5 dengan 
alternatif: sangat banyak (skor 5), banyak (skor 4), sedikit (skor 3), tidak ada (skor 2), tidak tahu (skor 1); (2) Penyusunan angket pengetahuan siswa terhadap pemanfaatan tanaman obat menggunakan skala Guttman dengan pilihan setuju dan tidak setuju. Pernyataan pada angket pengetahuan siswa mengenai pemanfaatan tanaman obat terdiri dari 10 pertanyaan Positif dan 5 pernyataan negatif, penskoran pernyataan Positif yaitu skor 1 untuk setuju dan 0 untuk tidak setuju. Penskoran untuk pertanyaan negatif yaitu 0 untuk pilihan setuju dan skor 1 untuk pilihan tidak setuju; (3) Penyusunan angket pengetahuan siswa terhadap pemanfaatan tanaman obat menggunakan skala guttman dengan pilahan setuju dan tidak setuju. Pernyataan pada angket pengetahuan siswa mengenai pengolahan tanaman obat terdiri dari 10 pertanyaan Positif dan 5 pernyataan negatif, penskoran pernyataan Positif yaitu skor 1 untuk setuju dan 0 untuk tidak setuju. Penskoran untuk pertanyaan negatif yaitu 0 untuk pilihan setuju dan skor 1 untuk pilihan tidak setuju.

Analisis data dalam penelitian ini mengunakan model Miles dan Huberman (Sugiyono,2007). Untuk menemukan presentase siswa yang merespon untuk setiap item, penulis analisis dengan mengunakan rumus yang dikemukakan oleh Sudijono(2010) sebagai berikut:

$$
\mathrm{P}=\frac{f}{N} \times 100 \%
$$

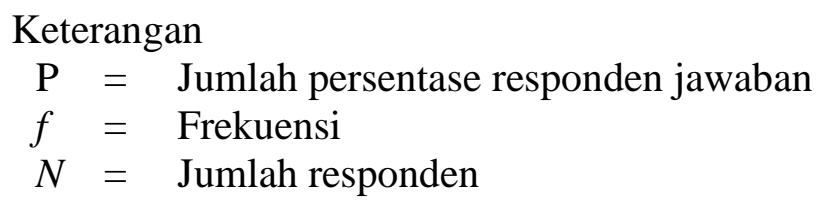

\section{HASIL PENELITIAN}

Data mengenai pengetahuan siswa terhadap tanaman obat telah didapatkan melaui penyebaran kuesioner kepada $15 \%$ dari total populasi yang tersebar merata di kelas VII yang berjumlah 141 siswa dan siswa kelas VIII berjumlah 131 siswa SMP Negeri 3 Kecamatan payakumbuh. Informan dalam penelitian ini ditetapkan sebanyak 41 siswa. Tanaman obat yang di jadikan sebagai indikator adalah tanaman yang umum digunakan masyarakat sebagai obat serta banyak ditemukan di sekolah. Tanaman yang di gunakan adalah Jambu biji, Lidah buaya, Jahe, Temulawak, Cabe rawit, Sirsak, Kunyit, Betadine, Seledri, Cocor bebek, Pepaya, Talas, Pisang, Lengkuas, Jeruk nipis.

Secara rinci aspek yang diteliti difokuskan pada tingkat pengetahuan siswa terhadap jenis dan pemanfaatan tanaman yang berkhasiat obat di lingkungan sekolah. Tinjauan tingkat pengetahuan ini meliputi indikator jenis-jenis tanaman obat yang terdapat di lingkungan sekolah, manfaat dan pengolahan tanaman obat. 


\section{Hasil analisa angket Tinjauan Pengetahuan Siswa terhadap Jenis - jenis Tanaman Obat yang Terdapat di Sekolah.}

Hasil pengolahan angket tinjauan pengetahuan terhadap jenis tanaman obat yang terdapat di lingkungan sekolah dapat di paparkan pada Tabel 1 di bawah ini.

Tabel 1. Hasil Analisa Tingkat Pengetahuan Siswa terhadap Jenis Tanaman Obat

\begin{tabular}{llcc}
\hline No & Jenis tanaman & Tingkat pengatahuan siswa (\%) & Kriteria pengetahuan siswa \\
\hline 1 & Jambu biji & 100 & Sangat mengetahui \\
\hline 2 & Sirsak & 85,9 & Sangat mengetahui \\
\hline 3 & Pisang & 81,5 & Sangat Mengetahui \\
\hline 4 & Betadin & 79,5 & Mengetahui \\
\hline 5 & Cabe rawit & 76,1 & Mengatahui \\
\hline 6 & Pepaya & 74,6 & Mengatahui \\
\hline 7 & Kunyit & 67,8 & Mengetahui \\
\hline 8 & Cocor bebek & 65,4 & Mengetahui \\
\hline 9 & Jahe & 64,9 & Mengetahui \\
\hline 10 & Lengkuas & 63,3 & Mengetahui \\
\hline 11 & Talas & 62,9 & Mengetahui \\
\hline 12 & Seledri & 57,1 & Cukup mengetahui \\
\hline 13 & Jeruk nipis & 49,3 & Cukup mengetahui \\
\hline 14 & Lidah buaya & 48,8 & Cukup mengetahui \\
\hline 15 & Temulawak & 40,5 & Cukup mengetahui \\
\hline & Rata-rata & $\mathbf{6 8 , 0}$ & Mengetahui \\
\hline
\end{tabular}

Tabel 1 di atas jika ditampilkan dalam bentuk grafik, maka dapat dilihat pada Grafik 1 berikut ini.

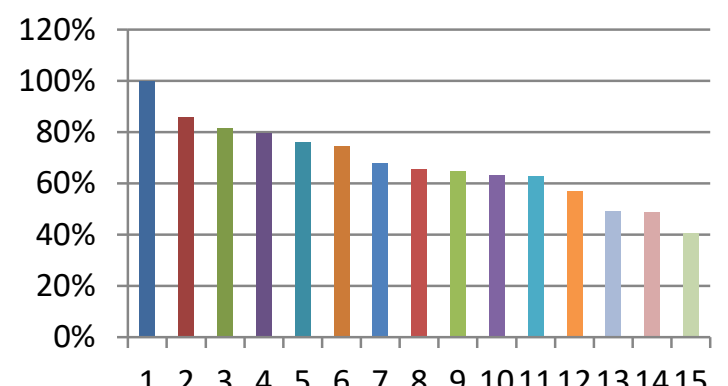

Jenis Tanaman

\section{Grafik 1. Tingkat Pengetahuan Siswa terhadap Jenis Tanaman Obat}

Dari Tabel dan Grafik 1 di atas dapat diketahui bahwa dari 15 jenis tanaman obat yang terdapat di sekolah, siswa sudah mengetahui bahwa tanamantanaman tersebut merupakan jenis tanaman yang berkhasiat obat. Tingkat pengetahuan siswa tersebar dari kriteria cukup mengetahui sebanyak 30\% dari total sampel, kriteria mengetahui sebanyak $45 \%$ dari total sampel dan sangat mengetahui sebanyak $25 \%$ dari total sampel.

Dari Tabel dan Grafik juga bisa terlihat bahwa dari 15 jenis tanaman obat yang di pertanyakan, siswa paling mengetahui jenis tanaman obat jambu biji, hal 
ini bisa disebabkan karena pohon jambu biji dapat dengan mudah ditemukan tumbuh di pekarangan atau kebun (Akbar, 2015). Selanjutnya tanaman yang juga paling dikenal oleh siswa memiliki khasiat obat adalah Sirsak diikuti oleh Pisang, Betadin, Cabe rawit, Pisang, Pepaya, Cocor bebek, Talas, Jahe, Lengkuas, Seledri, Lidah buaya, Jeruk nipis, Temulawak.

\section{Hasil Analisa Tinjauan Pengetahuan Siswa terhadap Manfaat Tanaman Obat yang Terdapat di Sekolah}

Hasil pengolahan angket tinjauan pengetahuan siswa terhadap manfaat tanaman obat yang terdapat dilingkungan sekolah dapat di paparkan pada Tabel 4.2 dan Grafik 4.2. Dari Tabel dan Grafik juga bisa terlihat bahwa dari 15 manfaat tanaman obat yang di pertanyakan, siswa paling mengetahui jenis tanaman obat Jambu biji sebagai tanaman obat yang di ikuti oleh Sirsak, Betadin, Jahe, Kunyit, Jeruk nipis, Lengkuas, Cocor bebek, Lidah buaya, Cabe rawit, Temulawak, Pepaya, Pisang, dan Talas.

Tingginya pengetahuan siswa terhadap manfaat tanaman obat jambu biji dikarenakan jambu biji termasuk buah-buahan yang mengandung vitamin $\mathrm{C}$, jambu biji juga bisa dimakan langsung atau dijadikan olahan dalam bentuk minumam atau sirup dan tanaman jambu biji juga mudah ditemukan di halaman atau di kebun.

Tabel 2. Hasil analisa Tingkat Pengetahuan terhadap Manfaat Tanaman Obat

\begin{tabular}{llcc}
\hline No & Manfaat tanaman obat & $\begin{array}{c}\text { Tingkat pengetahuan } \\
\text { siswa }(\boldsymbol{\%})\end{array}$ & $\begin{array}{c}\text { Kriteria pengetahuan } \\
\text { siswa }\end{array}$ \\
\hline 1 & Jambu biji & 100 & Sangat mengetahui \\
\hline 2 & Sirsak & 97,6 & Sangat mengetahui \\
\hline 3 & Betadin & 95,1 & Sangat mengetahui \\
\hline 4 & Jahe & 87,8 & Sangat mengetahui \\
\hline 5 & Kunyit & 82,9 & Sangat mengetahui \\
\hline 6 & Jeruk nipis & 75,6 & Mengetahui \\
\hline 7 & Lengkuas & 70,7 & Mengetahui \\
\hline 8 & Lidah buaya & 58,5 & Cukup mengetahui \\
\hline 9 & Cocor bebek & 58,5 & Cukup mengetahui \\
\hline 10 & Cabe rawit & 56,1 & Cukup mengetahui \\
\hline 11 & Temulawak & 53,7 & Cukup mengetahui \\
\hline 12 & Seledri & 53,6 & Cukup mengetahui \\
\hline 13 & Pepaya & 41,5 & Cukup mengetahui \\
\hline 14 & Pisang & 41,5 & Cukup mengetahui \\
\hline 15 & Talas & 17,1 & Tidak mengetahui \\
\hline & Rata-rata & 66,0 & mengetahui \\
\hline
\end{tabular}

Tabel 2 di atas jika ditampilkan dalam bentuk grafik, maka dapat dilihat pada Grafik 2 berikut ini. 


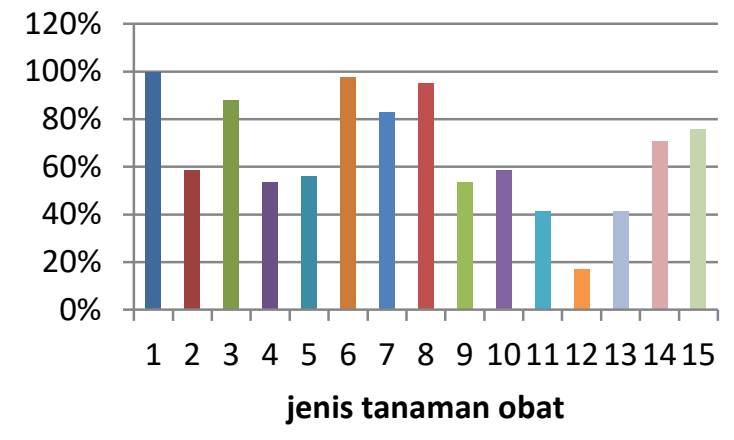

\section{Grafik 4.2 Tingkat Pengetahuan Siswa terhadap Manfaat Tanaman Obat}

Dari Tabel dan Grafik 2 dapat diketahui bahwa dari 15 manfaat tanaman obat yang terdapat di sekolah, siswa sudah mengetahui bahwa tanaman-tanaman tersebut memiliki manfaat tanaman yang berkhasiat obat. Tingkat pengetahuan siswa tersebar dari kriteria mengetahui sebanyak 33\% dari total sampel, kriteria mengetahui sebanyak $13 \%$ dari total sampel, kriteria cukup mengetahui sebanyak $46 \%$ dan tidak mengetahui sebanyak $6 \%$ dari total sampel.

\section{Hasil Analisa Tinjauan Tingkat Pengetahuan Siswa terhadap Pengolahan Tanaman Obat yang Terdapat di Sekolah}

Tingkat pengetahuan siswa tersebar dari kriteria sangat mengetahui sebanyak $40 \%$ dari total sampel, kriteria mengetahui sebanyak $33 \%$ dari total sampel, kriteria kurang mengetahui sebanyak 6\% dan kurang mengetahui sebanyak $6 \%$ dari total sampel. Tabel 3 di bawah ini menampilkan hasil analisa Tingkat pengetahuan siswa SMP Negeri 3 Kecamatan Payakumbuh terhadap pengolahan tanaman obat yang terdapat di sekolah.

Tabel 3. Hasil Analisis Tingkat Pengetahuan Siswa terhadap Pengolahan Tanaman Obat

\begin{tabular}{llcc}
\hline No & Pengolahan Tanaman obat & $\begin{array}{c}\text { Tingkat pengetahuan } \\
\text { siswa }(\boldsymbol{\%})\end{array}$ & $\begin{array}{c}\text { Kriteria pengetahuan } \\
\text { siswa }\end{array}$ \\
\hline 1 & Jambu biji & 97,5 & Sangat mengetahui \\
\hline 2 & Betadin & 92,6 & Sangat mengetahui \\
\hline 3 & Jeruk nipis & 87,8 & Sangat mengetahui \\
\hline 4 & Pepaya & 85,4 & Sangat mengetahui \\
\hline 5 & Lengkuas & 85,3 & Sangat mengetahui \\
\hline 6 & Cabe rawit & 82,9 & Sangat mengetahui \\
\hline 7 & Temulawak & 80,4 & Mengetahui \\
\hline 8 & Jahe & 78,0 & Mengetahui \\
\hline 9 & Pisang & 70,7 & Mengetahui \\
\hline 10 & Lidah buaya & 68,3 & Mengetahui \\
\hline 11 & Sirsak & 68,2 & Mengetahui \\
\hline 12 & Kunyit & 43,9 & Kurang mengetahui \\
\hline 13 & Seledri & 36,6 & Kurang mengetahui \\
\hline 14 & Cocor bebek & 36,6 & Kurang mengetahui \\
\hline 15 & Talas & 34,1 & Mengetahui \\
\hline & $\quad$ Rata-rata & 69,9 & \\
\hline & & &
\end{tabular}


Dari Tabel dapat terlihat bahwa tingkat pengetahuan siswa terhadap pengolahan tanaman obat yang terdapat di sekolah sudah tergolong baik, dimana siswa mengetahui bagaimana pengolahan tanaman-tanaman yang memilik khasiat obat.

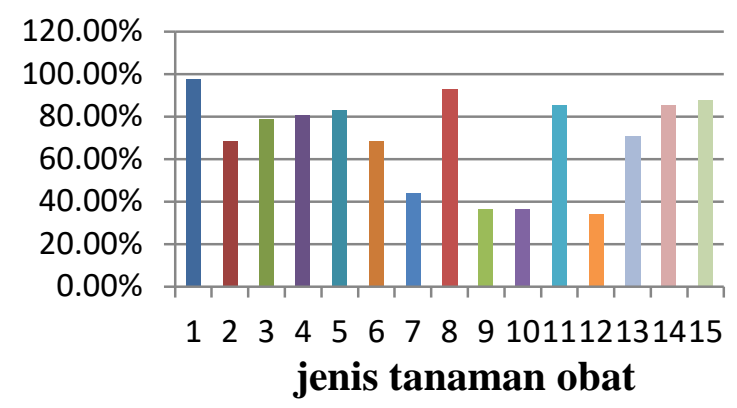

Grafik 3. Tingkat Pengetahuan Siswa terhadap Pengolahan Tanaman Obat

Pada Grafik dan Tabel 3 indikator pengolahan tanaman obat terlihat bahwa tanaman yang paling banyak di ketahui pengolahannya oleh siswa adalah jambu biji, karena jambu biji biasanya dimakan langsung buahnya, juga sering dijadikan olahan dalam bentuk minuman dan sirup.

Melalui Tabel dan Grafik juga bisa terlihat bahwa dari 15 manfaat tanaman obat yang di pertanyakan, siswa paling mengetahui cara pengolahan jenis tanaman obat Jambu biji sebagai tanaman obat yang di ikuti oleh Betadin, Jeruk nipis, Lengkuas, Cabe rawit, Pepaya, Temulawak, Jahe, Pisang, Sirsak, Lidah buaya, Kunyit, Seledri, Cocor bebek, dan talas.

\section{Rekapitulasi Tinujauan Pengetahuan Siswa terhadap Jenis Tanaman Obat, Manfaat Tanaman Obat dan Pengolahan Tanaman obat}

Secara indikator tinjauan pengetahuan siswa terhadap jenis, manfaat dan pengolahan tanaman obat yang terdapat dilingkungan sekolah dapat di paparkan pada Tabel 4 berikut ini.

Tabel 4. Rekapitulasi Tingkat Pengetahuan Siswa terhadap Jenis, Manfaat dan Pengolahan

\begin{tabular}{llcc}
\hline No & \multicolumn{1}{c}{ Indikator } & Rata rata $\%$ & $\begin{array}{c}\text { Kategori Pengetahuan } \\
\text { Siswa }\end{array}$ \\
\hline 1 & Jenis jenis tanaman obat & 68,0 & Mengetahui \\
\hline 2 & Manfaat tanaman obat & 66,0 & Mengetahui \\
\hline 3 & Pengolahan tanaman obat & 69,9 & Mengetahui \\
\hline
\end{tabular}




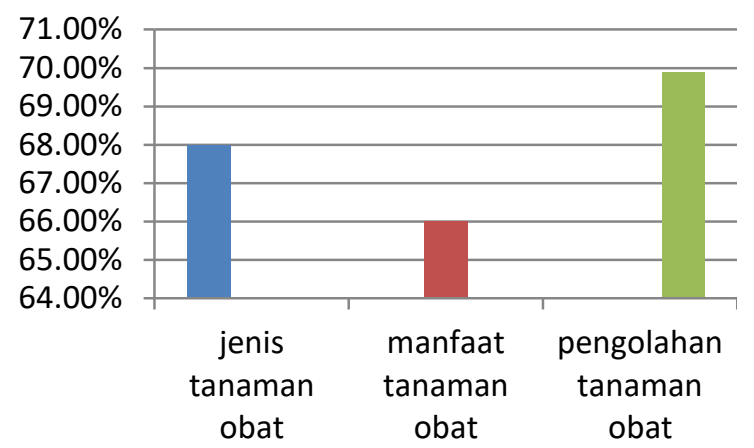

Grafik 4. Rekapitulasi Pengetahuan Siswa terhadap Jenis, Manfaat dan Pengolahan

\section{PEMBAHASAN}

Dari data diatas diketahui bahwa rata-rata tingkat pengetahuan siswa SMP Negeri 3 Kecamatan Payakumbuh terhadap jenis tanaman obat yaitu 68,0\% yang dikategori mengetahui, manfaat tanaman obat yaitu $66,0 \%$ yang dikategori mengetahui dan pengolahan tanaman obat yaitu $69,9 \%$ yang dikategori mengetahui.

Berdasarkan data maka telah diperoleh gambaran tinjauan tingkat pengetahuan siswa kelas VII dan siswa kelas VIII SMP Negeri 3 Kecamatan Payakumbuh terhadap jenis, manfaat dan pengolahan tanaman yang berkhasiat obat di lingkungan sekolah.

Hasil penelitian tentang Tingkat pengetahuan siswa kelas VII dan Siswa kelas VIII SMP Negeri 3 Kecamatan Payakumbuh tentang jenis tanaman obat, manfaat tanaman obat dan pengolahan tanaman obat terhadap indikator menunjukkan pengetahuan siswa tentang ketiga indikator tersebut termasuk kategori baik. Hal ini ditunjukkan oleh presentase rata-rata dari jawaban terhadap angket $\geq 60-80 \%$. Perhitungan data yang diambil menggunakan angket dengan skala likert bila berada pada rentang 60-80 dikategorikan baik (Riduwan, 2011: 89).

Baiknya Tingkat pengetahuan siswa tentang tanaman obat yang ada di lingkungan sekolah disebabkan karena beberapa hal diantaranya siswa telah mendapatkan program Adiwiyata disekolah. Selain itu buku-buku bacaan tentang tanaman obat juga tersedia diperpustakaan sekolah meskipun jumlahnya tidak banyak. Siswa juga memanfaatkan halaman sekolah untuk menanam tanaman obat dilingkungan sekolah. Tidak hanya itu di lingkungan sekolah juga terdapat Green House membantu siswa menambah pengetahuannya. Hal yang paling penting adalah pengalaman yang diperoleh siswa dilingkungan baik dengan mendengar, melihat, membaca atau bahkan menyaksikan akan membentuk pengetahuan bagi siswa.

Tingkat pengetahuan siswa tentang tanaman obat dengan indikator jenisjenis tanaman obat, pemanfaatan tanaman obat, dan pengolahan tanaman obat. Tingkat pengetahuan siswa SMP Negeri 3 Kecamatan Payakumbuh terhadap jenis tanaman obat yaitu sebesar $69,0 \%$ dengan kategori mengetahui. Tingkat pengetahuan siswa tentang jenis tanaman obat dikarenakan lingkungan sekitar atau masyarakat sering memanfaatkan tanaman sebagai obat. Hal yang mungkin 
mempengaruhi pengetahuan siswa ini adalah pengalaman atau kejadian dilingkungan siswa baik yang dilihat maupun yang didengar. Pengetahuan ini juga dapat diperoleh siswa dari program sekolah adiwiyata, dan buku-buku sumber tentang tanaman obat yang banyak menyajikan materi tentang manfaat tanaman yang berkhasiat obat.

Indikator manfaat tanaman obat sebesar 66,0 \% dengan kategori mengetahui. Hal ini diperkirakan dipengaruhi informasi yang siswa dapatkan dari guru-guru di sekolah yang memberikan pengetahuan tentang tanaman obat Sumber informasi tentang pengertian dan jenis tanaman obat lainnya juga banyak dijelaskan di internet dan buku sumber lainya.

Selanjutnya indikator pengolahan tanaman obat sebesar 69,9\% dengan kategori mengetahui. Bagusnya Tingkat pengetahuan siswa tentang pengolahan tanaman obat kemungkinan disebabkan karena siswa dapat belajar dari pengalaman masyarakat atau lingkungan mereka sendiri. Hal ini hampir sama dengan alasan seperti mengobati luka dengan tanaman betadin atau pengalaman dari teman. Selain dari pengalaman, dengan membaca buku sumber dan mengikuti lomba sekolah sehat dengan cara penghijauan lingkungan dan lomba UKS sekolah juga akan mendapatkan penjelasan tentang pengolahan tanaman obat.

Secara keseluruhan adalah siswa telah mengetahui dengan baik terhadap jenis tanaman obat, manfaat tanaman obat dan pengolahan tanaman obat. Dalam penelitian ini dapat disimpulkan bahwa tingkat pengetahuan siswa kelas VII dan siswa kelas VIII adalah mengetahui.

Pengetahuan merupakan hasil dari tahu, dan ini terjadi setelah orang melakukan penginderaan terhadap suatu objek tertentu. Penginderaan terjadi melalui panca indera manusia, yakni indera pengelihatan, pendengaran, penciuman, rasa, dan raba. Sebagian besar pengetahuan manusia diperoleh melalui mata dan telinga (Notoatmodjo, 2007).

Banyak faktor yang dapat mempengaruhi baik dan kurangnya pengetahuan seseorang. Faktor-faktor tersebut diantaranya yaitu pendidikan, semakin tinggi pendidikan seseorang maka makin mudah orang tersebut menerima informasi sedangkan pengalaman seseorang dapat memberikan pengetahuan dan keterampilan sehingga dapat memberi kemampuan mengambil keputusan secara. Penelitian ini dilakukan di SMP dimana umumnya siswanya telah mendapatkan pengetahuan pada pendidikan sebelumnya sehingga mudah memahami informasi.

Faktor lain yang mempengaruhi pengetahuan seseorang adalah ketersediaan informasi. Ketersediaan sumber informasi dapat memudahkan siswa untuk mengakses dan mendapatkan informasi baru mengenai tanaman obat. Teknologi informasi berkembang saat ini memiliki peranan yang sangat penting dalam mendapatkan segala informasi. Semakin banyak membaca informasi maka semakin banyak pula pengetahuan yang diperoleh.

\section{SIMPULAN}

Berdasarkan penelitian yang telah dilakukan maka diperoleh kesimpulan bahwa tingkat pengetahuan siswa SMP Negeri Kecamatan Payakumbuh adalah baik. Indikator pengetahuan tentang jenis tanaman obat sebesar 68,0\% yang diketegorikan baik. Indikator manfaat tanaman obat sebesar 66,0\% diketegorikan baik. Indikator pengetahuan tentang pengolahan tanaman obat sebesar $69,9 \%$ yang dikategorikan baik. 


\section{DAFTAR PUSTAKA}

Adfa, M. (2005). Study Senyawa Flavonoid dan Uji Brine Shrimp Beberapa Tumbuhan Obat Tradisional Suku Serawai di Provinsi Bengkulu. Jurnal Gradien 1(1): 43-50.

Agromedia, Redaksi. (2003). Ramuan Tradisional untuk Mengatasi Aneka Penyakit. Jakarta: PT Agro media.

Wirawati E.K, Tambunan L.A, \& Susanti, T. (2010). Daun Sirsak VS Kanker [online] di akses dari https://www.trubus-online.co.id/daun-sirsak-vskemoterapi-ribuan-kali-lebih-kuat/ tanggal 14 Maret 2019.

Akbar, R. (2015). Aneka Tanaman Apotek Hidup Di Sekitar Kita Dilengkapi Dengan Olahan Menarik. Yogyakarta: One Books

Darsini, N.N. (2013). Analisis Keanekaragaman Jenis Tumbuhan Obat Tradisional Berkhasiat untuk Pengobatan Penyakit Saluran Kencing di Kecamatan Kintamani Kabupaten Bangli Provinsi Bali. Jurnal Bumi Lestari 13(1); 159-165

Hariana, A. H., (2013). 262 Tumbuhan Obat dan Khasiatnya. Jakarta : Penerbit Swadaya.

Khomsan, A. (2006). Terapi jus untuk Kolestrol Ramuan herbal. Jakarta: Puspa Swara.

Koswara, S. (1995). jahe dan hasil olahannya. Jakarta: Pustaka Sinar Harapan.

Masyhud. (2010). Lokakarya Nasional Tanaman Obat Indonesia (TOI). Badan Litbang Kesehatan. Jakarta

Meleong, (2005). Metodelogi Penelitian Kualitatif. Bandung: PT Remaja Rosdakarya

Notoatmodjo, S. (2007). Promosi Kesehatan dan Ilmu Perilaku. Jakarta : Rineka Cipta.

Oktaviani, D. (2015). Tinjauan pemanfaatan Tanaman Obat di Kenagarian Halaban Kecamatan Lareh Sago Halaban Kabupaten 50 Kota (Skripsi). Payakumbuh: ST-KIP.

Riduan. (2011). Belajar mudah penelitian untuk guru - karyawan dan penelitian pemula. Bandung: Alfabeta

Sapriyawati. (2010). Tinjauan Umum Tentang Pengetahuan (https://www.google.com/search?ei=CZlyWuCOBov_vASuqqqIBQ\&q=pe ngetahuan + menurut + para + ahli + pdf\&oq=pengetahuan + menurut + para + ahli + pdf\&gs.com) Diakses 22 januari 2018

Saptriyawati. (2010). Tnijauan Tentang Tanaman Obat (https://saptriyawati.wordpress.com) Diakses 22 januari 2018.

Sudijono, A. (2010). Pengantar statistik pendidikan. Jakarta: PT. Raja Grafindo Algesindo

Sugiyono. (2007). Metode Penelitian Kuantitatif, Kualitatif dan $R \& D$. Bandung: Alfabeta Bandung

Trubus. (2010). Herbal Indonesia Berkhasiat: Bukti Ilmiah \& Cara Racik. Trubus Swadaya Volume 08; 355-356

Widodo. (2013). Psikologi Belajar. Jakarta : PT. Rineka Cipta. 